\title{
Monetary Calculation and Mises's Critique of Planning
}

\author{
Steven Horwitz
}

Over the last decade or so, there has been a renewed interest in the problems of economic calculation under socialism and a rethinking of the classic socialist calculation debate of the interwar era. A great deal of this work has been stimulated by Don Lavoie's (1985) reinterpretation of the debate that suggested a fundamental misunderstanding of the Austrian argument. In addition, the general growth of interest in Austrian economics since the mid-1970s, as well as the increasingly obvious failures of the so-called planned economies of Eastern Europe and the former Soviet Union, surely has played a role in the increased attention paid to these topics.

Although the general consensus of the literature since Lavoie's book has been that the Austrians were largely correct, ${ }^{1}$ not all of the writers have understood the full depth of the Mises-Hayek argument and its

Correspondence may be addressed to Professor Steven Horwitz, Department of Economics. St. Lawrence University, Canton NY 13617. E-mai]: shor@music.stlawu.edu.

I thank David Prychitko, Peter Boettke, Bruce Caldwell, Peter Lewin, Leland Yeager, participants at the 1996 History of Economics Society meetings in Vancouver, and two anonymous referees for comments and helpful discussions. I also thank Michael Greenwald for his assistance in checking various passages in the original German. Research for this article done during the summer of 1995 was supported by the Earhart Foundation.

1. See, however, Cottrell and Cockshott 1993 for one of the few reviews of the debate that is more skeptical of the Austrian victory. Steven Horwitz (1996) provides a response to their specific line of argument.

History of Political Economy 30:3 1998 by Duke University Press. 
implications for both economic theory and public policy. What many sympathetic to the Austrian approach have emphasized is the way in which the Mises-Hayek critique of planning reflected a uniquely Austrian conception of the market process, especially in comparison to the Walrasian approach of the market socialists of the 1930s. This interpretation of the debate is largely absent from more mainstream discussions of these issues. ${ }^{2}$

To provide some additional support for that interpretation of the debate, this article attempts to find the roots of Ludwig von Mises's argument for the linkage between a market economy and economic calculation in his 1912 book The Theory of Money and Credit (TMC). ${ }^{3}$ What emerges in that book and is later amplified in Mises's discussion of monetary calculation in Human Action ([1949] 1966) is that calculation in terms of money is central to the market economy and the expansion of wealth it brings. Of equal importance for Mises is that economic calculation is only necessary in a world where capital goods are understood to be heterogeneous and only possible where those heterogeneous capital goods are privately owned and exchanged for money in a genuine market. These interconnections between heterogeneous capital, monetary calculation, and economic systems also demarcate Mises's distinctly Austrian approach from the ways in which modern neoclassical economics (particularly in its Walrasian variant) has attempted to compare economic systems.

There are two important implications of this argument. First, given that later participants in the calculation debate (including F. A. Hayek) downplayed Mises's emphasis on monetary calculation and ignored its relationship with the use and functions of money and monetary institutions, a reemphasis of the monetary roots of the Mises critique enables us to view the calculation debate through a fresh lens. It also lets us see the knowledge problems raised by Hayek, Israel Kirzner, and Lavoie in the context of Mises's argument about the way in which monetary calculation enables entrepreneurs to formulate plans in the face

2. In his recent book, Joseph Stiglitz (1994) does see that both he and F. A. Hayek share a rejection of the Walrasian model as a basis for understanding alternative economic systems. However, as Peter Boettke (1996) argues, Stiglitz, in several places in his discussion of Hayek, does not seem to understand how radical the Austrian rejection of general equilibrium theory really is, nor does he truly escape the Walrasian model when it comes to bis criticisms of Hayek.

3. In a recently published posthumous essay, Murray Rothbard $(1995,62)$ argues that TMC was the "main impetus" for the 1920 article. 
of an uncertain future. Second, this perspective reveals how the MisesHayek critique of planning was solidly grounded in the distinctly subjectivist approach of the Austrians that is evident in a work like TMC, which was on the surface not part of the calculation debate. Highlighting these paradigmatic differences from the perspective of the role of money reveals the consistency between Mises's arguments and those of Hayek and modern Austrians, as well as the problems faced by Walrasian attempts to assess economic systems.

\section{A Brief Overview of the Socialist Calculation Debate}

The socialist calculation debate is generally acknowledged to have begun with Mises's 1920 article "Economic Calculation in the Socialist Commonwealth." The main theme of the article was that social ownership of the means of production prevented any planning agency from being able to allocate resources rationally, that is, satisfy consumer wants by using the least-valuable resources possible. Mises argued that economic calculation requires that the means of production (capital goods) have money prices that can be used to compare supply and demand or profit and loss. For capital goods to have money prices, they must be exchanged in a market. And for market exchange to exist, there must be private property in those capital goods. Economic calculation and private property in the means of production are inseparable: "Where there is no free market, there is no pricing mechanism; without a pricing mechanism, there is no economic calculation" (Mises [1920] 1935,111 ).

Mises's elaboration of this point centered around the use of money prices. He was quite clear in claiming that prices are able to be "aids to the mind" because they result from monetary exchange. In his discussion of the socialist state, Mises argued that the absence of a market for the means of production would drastically limit the use of money. ${ }^{4}$

4. The use of money in existing socialist economies is a cloudy concept. Mises's claim that money and socialism are incompatible runs up against apparent counterevidenec of the use of money in nominally socialist regimes across the world. The key to the apparent contradiction is to recognize that to the extent such regimes genuinely allowed the use of money and monetary exchange they were not truly socialist. Mises rightly points out that in an economy where the means of production are socialized but consumption goods are not, money's range of influence will be narrower. Without monetary exchange for capital goods, calculation will not be possible and economic performance will suffer. However, if other goods are genuinely 
"The significance of Money in a society where the means of production are State-controlled will be . . incomparably narrower, since the material available for exchange will be narrower, inasmuch as it will be confined to consumption-goods. Moreover, just because no productiongood will ever become the object of exchange, it will be impossible to determine its monetary value. .. . Calculation in terms of money will be here impossible" (92). After rejecting arguments that such calculations could be made on the basis of some kind of labor unit, Mises expanded on money's role in the valuation process: "Monetary calculation has its limits. Money is no yardstick of value, nor yet of price. Value is not indeed measured in money, nor is price. They merely consist in money" (98).

Money prices give us guideposts to "orientate [ourselves] properly among the bewildering mass of intermediate products and potentialities of production" (103). Mises summarized his argument: "Moreover, the mind of one man alone - be it never so cunning, is too weak to grasp the importance of any single one among the countlessly many goods of a higher order. No single man can ever master all of the possibilities of production, innumerable as they are, as to be in a position to make straightaway evident judgments of value without the aid of some system of computation. The distribution among a number of individuals of administrative control over economic goods . . . entails a kind of intellectual division of labour, which would not be possible without some system of calculating production and without economy" (102; emphasis added). It is the notion of an "intellectual division of labor" that forms the core of the later Hayekian contributions to the critique of central planning. The planners have to explain how they will know, in the absence of money prices, whether, for example, a bridge should be built of steel, iron, or wood. Mises, in his book-length treatment of these issues ([1922] 1981, 123), argues that without private property in those means of production, there can be no money prices: "Economic calculation can only take place by means of money prices established in the market for production goods in a society resting on private prop-

traded against money and prices are not state controlled, then those sectors will perform better. The upshot of this is that referring to Soviet-style economies as "socialist" is to give them too much credit. Indeed, for Mises or Hayek to have referred to those economies as "socialis $t$ " seems to fly in the face of their own arguments against the possibility of having a planned economy. See the discussion in Polanyi 1957. 
erty in the means of production." Without these money prices, rational economic calculation is indeed impossible.

It is worth noting again that Mises frequently, though not always, uses the term money prices rather than just prices or, as we might more likely say today, market prices. For Mises, the issues surrounding economic calculation were bound up with a money-using economy, which, he believed, was of necessity one with private property in the means of production.

The lost emphasis on money is particularly important in light of Lavoie's argument that the neoclassical market socialists such as Oskar Lange misunderstood the Austrian conceptions of competition and markets, mistakenly believing that they too were thinking in terms of equilibrium theory. The key to Lange's ([1936] 1964) response to Mises was his claim that Mises referred to only one of two possible notions of price: "It may mean either price in the ordinary sense, i.e., the exchange ratio of two commodities on a market, or it may have the generalized meaning of 'terms on which alternatives are offered.' ... It is only prices in the generalized sense which are indispensible to solving the problem of the allocation of resources. . . But Professor Mises seems to have confused prices in the narrower sense ... with prices in the wider sense of 'terms on which alternatives are offered" (Lange [1936] 1964, 59-61).

For Lange, the vector of relative prices produced by a general equilibrium solution was just as able to guide economic calculation as were the money prices referred to by Mises. Lange went on to show how the solution to the general equilibrium allocation problem was independent of the ownership of the means of production. A planning board was just as, if not more than, capable of solving for equilibrium prices as was the market. In deploying the tools of mainstream microeconomic theory to make his point, Lange successfully convinced the overwhelming majority of economists that economic theory alone could not claim that planning was less desirable than markets.

In Hayek's well-known essays on economics and knowledge between 1937 and 1945, he rightly criticized the equilibrium focus of the market socialist argument. Most of those criticisms took one of two forms. The simpler point was that equilibrium theory was irrelevant to the problem because some number of markets had features that did not match the assumptions necessary for perfectly competitive equilibrium to obtain (e.g., nonstandard goods). The more profound point was that solving 
for equilibrium prices involved assumptions about knowledge that could never be fulfilled in the real world. In Hayek's [1937] 1948 article, "Economics and Knowledge," he defined equilibrium in terms of plan consistency, implying that equilibrium required a high degree of knowledge among market actors. The task of economics was to explain how market processes empirically discovered and communicated the knowledge that equilibrium theory assumed was already possessed by market actors. In "The Use of Knowledge in Society" ([1945] 1948), Hayek argued that the economic problem is about overcoming the dispersed and fragmented knowledge held by individuals.

As accurate as these arguments were, and as much as they were crucial to the recent revivial of Austrian economics, they largely neglected the original monetary themes that pervaded Mises's 1920 article. Returning to those themes could have been, and still remains, one way of distinguishing the market process approach of the Austrians from the equilibrium orientation of Lange and others. General equilibrium models are of necessity moneyless, and it would make sense for Lange to attempt to finesse the meaning of price to avoid Mises's arguments about money prices. Mises's major point, to be explored below, was that it is the process of exchanging against money that enables prices to become socially meaningful and to serve in the process of economic calculation. It was through the process of actual exchanges against money that competing entrepreneurs endowed prices with their own appraisals of existing and expected market conditions. The parametric accounting prices of a Langean trial-and-error process do not reflect active appraisals by competing entrepreneurs and thus fail to serve as the calculative aids that Mises argues are necessary. By contrast, in a nonequilibrium world such as that at least tacitly adopted by the Austrians, it is real-world money prices that matter for the coordinative properties of alternative schemes involving the ownership of the means of production.

\section{The Monetary Roots of Mises's Critique of Planning}

To see why Mises thought that the debate over economic calculation needed to take the role of money and money prices seriously, we can begin by exploring his several references to economic calculation and economic systems in The Theory of Money and Credit. As noted earlier, 
the book was written in German in 1912. A second German edition, issued in 1924, serves as the basis for the various English translations. To argue that the references in TMC precede the 1920 calculation article, it is necessary to show that the relevant passages appear in the first German edition as well. In the quoted passages below, I provide the page numbers to the 1980 Liberty Classics edition, along with the matching pages in the 1912 German edition.

The Theory of Money and Credit is today recognized for several different significant contributions. Mises's main intent in writing the book was to show how the Austrian-subjectivist theory of marginal utility could explain the value of money. His famous regression theorem, which traced the value of money back to the exchange value of the money commodity, enabled him to escape from the presumed infinite regression that was believed to prevent any explanation of the value of money. The book is also known for Mises's discussion of the limits of aggregative quantity theory approaches, his explanation of the problems of inflation, and his wedding of Austrian monetary theory to Knut Wicksell's theory of the natural and market rates of interest in order to sketch what would later be known as the Mises-Hayek (or Austrian) theory of the business cycle. Beyond all of these contributions, the book is also a broad introduction to the origin and functions of money and money's place in a market society. 5

That Mises believed there was a strong relationship between the use of money and questions concerning the private or public ownership of the means of production is evident from the first pages of TMC. He begins, "Where the free exchange of goods and services is unknown, money is not wanted" $(1980,41 ; 1912,3)$. He goes on to offer two examples of such a scenario. The first is an earlier time when the division of labor was a "domestic" matter, while the second is the case where "the means of production are socialized." In a sketchier version of a theme that was developed more fully in 1920, Mises also argues that "the phenomenon of money presupposes an economic order in which production is based on division of labor and in which private property consists not only in goods of the first order (consumption goods) but also in goods of higher orders (production goods). In such a society ... production is 'anarchistic'" (Mises 1980, 41; 1912, 3).

5. In this respect, its themes parallel those of Simmel [1907) 1978.

6. In the German, Mises uses the more Marxian syntax of "Anarchie der Produktion." 
From the start, the existence and use of money is inherently linked with private property in the means of production.

Given the intellectual atmosphere in early-twentieth-century Vienna, it is not surprising that Mises would begin a book on money in this way. Marxism and other forms of socialism were the causes of the day, and contemporary Marxists such as Rudolf Hilferding understood the link between money and private property, only they wished to do away with both. ${ }^{7}$ Having interacted with some of the era's major socialist thinkers in Eugen Böhm-Bawerk's seminar (foremost among them Otto Neurath), Mises likely saw one audience for his book as being those who wished to abolish the use of money.

The relationship between money and private property becomes clearer toward the end of the second chapter, "The Measurement of Value." Mises $(1980,62 ; 1912,30)$ argues that in order for individuals to allocate their resources in ways that achieve maximum utility, they must be familiar with all of the exchange ratios on the market. Money, which exchanges against all commodities, dramatically simplifies this comparison process: "Because the market enables any commodity to be turned into money and money into any commodity, objective exchange value is expressed in terms of money." Mises, on the same page, then relates this point to the issue of economic calculation: "The whole structure of the calculations of the entrepreneur and the consumer rests on the process of valuing commodities in money. Money has thus become an aid that the human mind is no longer able to dispense with in making economic calculations." As early as 1912, Mises understood that money, and money prices, which could only emerge with private property in both consumption and production goods, were necessary for rational economic calculation.

This particular passage raises two points in relation to Mises's later work on the problems of socialism. The first is his reference to money as an "aid [for] the human mind." This is of interest because he uses almost the same phrase in the 1920 calculation article. In the context of his discussion of the conditions necessary for calculating value in terms of money (again, parallel to the discussion in TMC), Mises ([1920] 1935, 102; emphasis added) argues that "only under simple conditions

7. See Hilferding [1910] 1981, 35: "The necessity of money thus arises from the nature of commodity producing society. ... The necessity to mediate exchange through money ... arises from the anarchy of commodity producing society." 
can economics dispense with monetary calculation... . [In such a case] it is possible to determine the significance of changes in the processes of production without such aids to the mind." The use of such similar phrasing, and in such a similar context, suggests that Mises was pretty clear on the essentials of the critique of planning as early as the writing of TMC. ${ }^{8}$ One could infer that he understood money and monetary exchange to be central to economic calculation.

The second point of interest related to this passage in TMC is that Mises added a footnote to the second, translated, edition at the end of the quoted passage. The footnote directs the reader to his 1922 book Socialism for more "on the indispensability of money for economic calculation" (Mises 1980, 62). This, again, suggests Mises's own line of thinking. Presumably on going back to undertake the revisions for the second edition, he intended to point his reader to the interconnections between the two books.

\section{The Epistemic Role of Monetary Calculation}

Later extensions of the critique of planning, particularly by Hayek and Lavoie, have emphasized the way in which the price system serves as a communication process. ${ }^{9}$ The argument is that market prices are socially accessible proxies for the imperfect subjective evaluations of both consumers and producers. A market price makes available the otherwise inaccessible subjective cost and utility evaluations of market actors. The claim by Hayek and Lavoie is that a socialist planner would have no alternative method of directly or indirectly accessing those subjective evaluations. In addition, planners would find it much more difficult to learn from their mistakes than would market entrepreneurs, due to the absence of prices reckoned in money, and would therefore be unable to use resources as rationally. Although it is true that Mises never made this point as clearly as did later participants, two passages in TMC and a parallel one in the 1920 article suggest that he also saw prices, specifically money prices, as "objective" reflections of subjective values.

In his discussion "The Objective Exchange Value of Money," Mises

8. I have been unable to compare the German in TMC to the original German of the 1920 calculation article.

9. For more on this issue see Hayek [1945] 1948; Hayek 1978; Lavoie 1986; Boettke 1993, chap. 3; Steele 1992; and Horwitz 1992b. 
begins $(1980,121 ; 1912,97-98)$ with a more general discussion of the objective exchange value of any good. He quotes Böhm-Bawerk's definition of objective exchange value as the "capacity in given circumstances to procure a specific quantity of other goods as an equivalent in exchange." He goes on to point out that a good's objective exchange value is not a property of the good itself but "is derived from the human process of valuing individual goods.... The exchange ratios that are established between different goods in commercial transactions ... are determined by the collective influence of the subjective valuations of all the persons doing business in the market." In other words, market prices (i.e., those derived from monetary exchange) are reflections of the subjective knowledge of the various market participants. In addition, the first two sentences of the chapter that contains his famous regression theorem make this point even more clearly: "According to modern value theory, price is the resultant of the interaction in the market of subjective valuations of commodities and price goods. From beginning to end, it is the product of subjective valuations" $(1980,129$; $1912,104)$. Monetary exchange enables these subjective evaluations to become "objectively" usable by translating them into a single numerical referent, a money price.

Perhaps the most telling passage along these lines in TMC is the first two sentences in the section where Mises introduces his cash balance approach to the demand for money. In emphasizing that all demands, including that for money, are based on subjective value theory, Mises says, "The process, by which supply and demand are accommodated to each other until a position of equilibrium is established and both are brought into quantitative and qualitative coincidence, is the higgling of the market. But supply and demand are only the links in a chain of phenomena, one end of which has this visible manifestation in the market, while the other is anchored deep in human mind" (1980, 153; 1912, 141).

Movements in market prices (the "visible manifestations") simply reflect changes in the underlying subjective evaluations, which, without monetary exchange in a market, would otherwise go uncommunicated. Although it is not as clearly articulated as Hayek's later contributions, it does seem clear that Mises sees the price system as coordinating what Hayek ([1945] 1948, 77) called "the dispersed bits of incomplete and frequently contradictory knowledge which all the separate individuals possess." One can also compare this line of argu- 
ment in TMC to Mises's use of the phrase "intellectual division of labor" in his 1920 discussion of the advantages of market competition over centralized planning.

In a series of recent articles, Joseph Salerno (1990, 1993, 1994; see also Rothbard 1995, 60-72) has tried to demonstrate that Mises's emphasis on economic calculation is distinct from Hayek's later focus on the knowledge problem facing socialist planners. Salerno argues not only that these are distinct criticisms that have been conflated, but that Mises's is the more fundamental one. Salerno attempts to distinguish between what Mises referred to as "calculation" and the Hayekian discussion of "knowledge." In Salerno's view, even if the planner had perfect knowledge of the various production possibilities and human wants, he would still be unable to plan because he would lack a basis for meaningfully comparing those alternatives. For Salerno, Mises's discussion of monetary calculation shows why the knowledge question is not the central issue. The real sticking point for planners is that they have no equivalent of monetary calculation to guide them. Most of Salerno's argument is based on Mises's discussion of calculation in Human Action.

Mises continued to hold to his belief that monetary exchange was the foundation of economic calculation up to the third edition of Human Action ([1949] 1966). However, what is interesting for the argument at hand is that his views on this issue appear not in chapter 26, "The Impossibility of Economic Calculation under Socialism," but in the earlier part 3, "Economic Calculation," comprising chapters 11, 12, and 13. In particular, the section in chapter 11 titled "The Problem of Economic Calculation" has a discussion very close to that of TMC and the 1920 article. As Salerno $(1990,40)$ rightly points out, this is because Mises believed that economic calculation fell under the analysis of human action in general and was thus preliminary to exploring the market (or attempts to dispense with it) as an economic system. Mises always conceived of calculation in terms of money prices as central to our ability to formulate individual plans and our attempts to carry them out in a world of uncertainty. Before one went on to examine the market in detail and compare it to other economic systems, one had to understand human action and its relationship to the ability to calculate rationally by using money prices.

As noted before, Mises ([1949] 1996, 206-7) sees the necessity of calculation through the use of money prices as deriving from the prob- 
lem of allocating capital goods (goods of the higher orders) toward the production of final goods. In a world where capital goods can produce alternative final goods and where, therefore, choices must be made as to which processes to devote them to, the allocator of capital goods must have some basis for comparison. If all capital goods are perfectly substitutable, no calculation is necessary, as no choice needs to be made. If all capital goods are perfectly specific, such choices are also not necessary, because each capital good has one and only one use to which it can be put. Where a final good has a number of technologically feasible methods of production involving inputs with multiple alternative uses, the producer needs some way of comparing the technologically feasible methods to determine which is the most economically rational. This is the role of monetary calculation: "Such comparisons can only be made by the use of money prices" (Mises [1949] 1966, 208).

Mises goes on to argue that economic calculation is limited to those "things which are . . bought and sold against money" (214). This derives from money's role as the "universally used medium of exchange . . because most goods and services can be sold and bought on the market against money, and only so far as this is the case, can men use money prices in reckoning" (208-9). For Mises, the importance of monetary calculation is that it "is the guiding star of action under the social system of the division of labor" (229). Whenever we act in the market, we make use of monetary calculation to determine which actions to take (ex ante) and to reckon (ex post) the results of those actions: "The premeditation of planned action becomes commercial precalculation of expected costs and expected proceeds. The retrospective establishment of the outcome of past action becomes accounting of profit and loss" (229)..$^{10}$ Mises adds that our ability to have this "guiding star" is dependent upon certain social institutions, namely, "the division of labor and private ownership of the means of production" (229). The rationale here is that only under private ownership will the means of production trade in a true market against a common medium of exchange, enabling us to attach meaningful prices to them.

Monetary calculation is intricately linked with Mises's conception of the entrepreneur. Salerno (1990) has rightly called attention to Mises's very important discussion of valuation and "appraisement." What

10. Compare the similar, if somewhat more abstract, point in Hayek 1977, 107, 166, as well as the similar discussion in Boettke 1990, 130-31. 
entrepreneurship is for Mises is the formulation of an expectation of the future constellation of prices and the attempt to see opportunities within that vision that others do not currently notice. ${ }^{11}$ One primary factor in the entrepreneurial appraisement of future prices is the constellation of current prices. Entrepreneurial action begins with past prices and brings them together with what Mises refers to as the "faculty of understanding" (which, in more contemporary terms, might be termed "the process by which the agent's expectations are formed") to fix concrete expectations of future prices. Based on those expectations, the entrepreneurial aspect of human action leads us to choose what we interpret to be the appropriate course of action. It should be clear from this discussion that entrepreneurship in the market, that is, the formulation of plans of action, is crucially dependent on the existence of money prices that can inform these acts of appraisement. Without such prices, there would be no basis on which such entrepreneurs could formulate their plans or reckon their results.

\section{Reconciling Mises and Hayek}

The problem with Salerno's argument is that he believes that Mises's emphasis on the importance of calculation is distinct from, and superior to, Hayek's later emphasis on the importance of knowledge. Salerno appears to interpret the Hayek-Kirzner-Lavoie argument as being a claim that the price system provides something close to a perfect reflection of the information possessed by actors in the market. This supposed near-perfect reflection stands in contrast to the ignorance of such knowledge that would plague planners. Although this is one plausible reading of Hayek (and one which is frequently adopted by information economists), the recent contributions of Esteban Thomsen (1992) and Kirzner (1992) make it clear that it is neither the only reading of Hayek nor the most plausible. Instead of a focus on the fullinformation properties of equilibrium prices, the Hayek-Austrian argument is really about the ability of imperfectly informative disequilibrium prices to provide guidance through a world of uncertainty. Read this way, Hayek's point seems virtually identical to Mises's discussion

11. Kirzner's (1973) debt to the Misesian conception of the entrepreneur is quite obvious in this discussion, as Kirzner, of course, recognizes. It should be reiterated that entrepreneurship is understood by both Mises and Kirzner as an aspect of human action, rather than a flesh-and-blood (or ideal-type) actor. 
of entrepreneurial appraisement. Interpreted in equilibrium terms, the Mises notion of appraisement is simply the entrepreneur spotting what he perceives as current disequilibria by creatively imagining a more equilibrating future constellation of prices. This, of course, is also the role of Kirzner's entrepreneur. Salerno's view of the Hayekian knowledge argument - that existing prices embody full and correct information-is more associated with Hayek's neoclassical descendants (Kirzner 1996, 149).

This misreading of Hayek seems to derive from the mistaken belief that when Hayek uses the terms spontaneous and undesigned he means something like "having no relationship to rationally planned human action." On such a view it would make sense to see prices as providing full and accurate information because supposed irrational Hayekian actors would need such information, being unable to act in a calculative manner. ${ }^{12}$ Yet such a view is clearly wrong. Hayek $(1967,96-105)$ has always defined spontaneous orders, following Adam Ferguson, as "the results of human action but not of human design." Thus calculative rational action in terms of money prices is indeed what sets spontaneous ordering processes into motion, but the ultimate order that results reflects the deliberate intentions of none of the choosers involved. This is best seen in Carl Menger's theory of the origin of money, where purposive, intentional decisions by traders to use indirect exchange lead to an outcome (a generally accepted medium of exchange) that none of them need have intended or foreseen. ${ }^{13}$

Thus there is no conflict between Mises's discussion of the purposiveness of calculation and appraisement and Hayek's discussion of the spontaneous order that results. When Hayek argues that we frequently do things without understanding why we do them, particularly in the context of the price system, he is simply saying that an entrepreneur who utilizes prices and other informational shorthands is acting based on those shorthands rather than complete, articulated knowledge of

12. Murray Rothbard (1995, 55; emphasis added) appears to take this view of Hayek when he says, "The free price-system is vital to the entrepreneur but it is not, as in Hayek-Kirzner, his only source of knowledge." As with much of Rothbard's and Salerno's case against Hayek and his followers, no textual citation is provided to demonstrate where Hayek or Kirzner (or Lavoie) ever made the claim that the only piece of knowledge entrepreneurs need is price signals.

13. Mises ([1949] 1966, 405-8) recognized Menger's theory and, specifically, its discussion of unintended consequences, by noting its importance for "the elucidation of fundamental principles of praxeology and its methods of research." 
what he is doing. Hayek's ([1945] 1948, 85-86) famous example involving the price of tin illustrates this point: Market actors need not have detailed knowledge of the changing subjective and objective circumstances in order to make efficiency-enhancing choices. People act with the help of signals without understanding completely why those signals are changing. If Hayek were completely dismissing the possibility of rational action by individuals, how does one make sense of his repeated claim that spontaneous orders are comprised of the multitude of consciously calculating individuals and organizations we know as families and firms (Hayek 1973, 46-54; Hayek 1989, 37)? ${ }^{14}$

We can reconcile the Mises and Hayek accounts in the following way. Money prices serve as imperfect substitutes for the knowledge possessed by individual actors. The existing constellation of money prices is the unintended consequence of previous entrepreneurial appraisements colliding with the wants of consumers and changes in the physical and technological environment. These prices, though causally unconnected to future prices, do serve as the starting point for the next round of entrepreneurial appraisement, because they do provide (imperfect) information about scarcity, wants, and opportunity costs. This process of utilizing past money prices to appraise possible future money prices by using the faculty of understanding is what Mises calls monetary calculation. It is also the knowledge-discovering process pointed to by Hayek. ${ }^{15}$ The link is what Salerno refers to as the "social" nature of the appraisement process, that is, it incorporates the

14. In his zeal to portray Mises as the true "rationalist," Salerno plays a little loose with Mises's own words. For example, Salerno $(1990,39)$ describes Mises's view of monetary calculation as, quoting Mises, a "'method of thinking' purposefully created by 'acting man' which "made it possible to calculate his actions." Note that the word purposefully is not Mises's word, but Salerno's. The exact quote from Mises is "[praxeology and economics] could only emerge when acting man had succeeded in creating methods of thinking that made it possible to calculate his actions" ([1949] 1966, 231). Mises"s word creating is surcly more ambiguous than purposefully with respect to whether monetary calculation was deliberately invented with a conscious recognition of its ultimate consequences or whether it was simply "created" to ease the planning process facing an individual entrepreneur and then cvcntually evolved into a widely used social institution. The latter is a position completely consistent with Hayekian spontaneous order theory.

15. See also Kirzner 1996, 153: "But the circumstance that in fact current market prices reflect that corrective market process (and our awareness that Mises did indeed emphasize this circumstance in regard to market prices) should convince us that an appreciation of the role of market prices stated in terms of the 'Hayekian' knowledge problem is simply a somewhat differently articulated appreciation for the calculative properties Mises taught us to understand to exist in those market prices." 
judgment of a multitude of human actors. By implication, planners could not duplicate the social aspect of market appraisement processes, because planning would necessarily substitute the judgment of a smaller number of persons for the multitude participating in the market. Despite Salerno's $(1990,44)$ insistence to the contrary, it is in this sense that monetary calculation is central to the market's ability to discover and utilize knowledge. The money prices that facilitate such calculations are shorthand for an immense amount of historical knowledge. 16 It is not the case that humans are so irrational as to have to "blindly" follow price signals; nor do such signals provide all of the knowledge they need. Rather, those price signals assist them in forming rationally constructed production plans by condensing detailed (if imperfect) knowledge to a single cardinal number.

When read in conjunction with this later and broader discussion in Human Action, the aforementioned passages in TMC suggest a more unified vision of Mises and Hayek's argument. The Hayekian claim that prices are conveyors of knowledge is simply a further development of Mises's view that money prices are objective resultants of subjective evaluations on both sides of the market. Where Mises questioned the ability of a planner to comprehend all of the production possibilities in the absence of "aids to the mind," Hayek simply refined what the epistemic role of prices was. ${ }^{17}$ In particular, Hayek's emphasis on the contextuality and inarticulateness of market knowledge explains why the knowledge that is needed to determine the efficient use of capital goods can only come through monetary calculation in the competitive market process, and not through any other information-gathering process.

To see this point more clearly, we can return to Mises's discussion of the role of "understanding" in the process of monetary calculation. Entrepreneurs use their understanding of the wants, behavior, and attitudes of others (what Mises ([1957] 1985) called "thymological knowledge") to form expectations about future wants and the future constel-

16. In fact, Salerno $(1990,44)$ coneedes this point in his discussion of Mises's hypothetical scenario, where the memory of all past prices fades away. Salerno approvingly quotes Mises as saying, "It would [then] be necessary for [entrepreneurs] to assemble anew all the data they need as the basis of their operations. They would not avoid mistakes which they now evade on account of experience at their disposal" (Mises [1949] 1966, 337). It seems utterly plausible to see Mises as saying that prices perform a "Hayekian" epistemic function herethey provide information to entrepreneurs that would otherwise be absent.

17. This is essentially Leland Yeager's (1994, 1996) position in his contribution to the debate sparked by Salerno's attempt to distinguish Mises and Hayek on this issue. 
lation of prices. Mises is explicit in saying that "understanding is always based on incomplete knowledge" and that understanding is necessary "in dealing with the uncertainty of future events" (Mises [1949] $1966,112,58$ ). It is through the use of understanding that we form the expectations about others necessary to formulate plans in an uncertain world. One way of seeing the Hayekian argument about the epistemic role of prices is to see them as distillations of the very detailed knowledge that we could acquire through an explicit process of understanding. By having access to money prices, actors can formulate expectations of the future (appraisement) without needing to acquire detailed specific knowledge. In addition, money prices, by virtue of their ongoing and prior use in the market, carry with them a certain sense of "objectivity." Hayek's emphasis on tacit knowledge simply reinforces Mises's emphasis on the role of understanding, as Hayek points out how prices might well embody more knowledge than could be acquired by methods that rely on articulate information. Money prices make economic calculation possible by serving as crystallizations of more detailed (and possibly inaccessible) knowledge. On this view, the messages of Mises and Hayek are indeed consistent.

It is true that Hayek's later contributions strongly downplayed the idea of monetary calculation, instead focusing on the broader knowledge issues. However, one way of reading the shift in emphasis is that Hayek simply took for granted that Mises's original claim in the 1920 article was correct and clear, so that Hayek no longer needed to make the point. Instead, Hayek's new opponents required further developments of what Mises was saying. As Hayek points out in the first section of his 1940 response to the market socialists, he could then "regard as closed" that section of the calculation debate which dealt with whether or not socialism could "dispense entirely with calculation in terms of value" ([1940] 1948, 181). Hayek goes on to say that "the criticisms of the earlier socialist schemes have been so successful that the defenders, with few exceptions, have felt compelled to appropriate the arguments of their critics and have been forced to construct entirely new schemes of which nobody had thought before. . . But it is surely unfair to say, as Lange does, that the critics, because they deal in a new way with the new schemes evolved to meet the original criticism, "have given up the essential point' and 'retreated to a second line of defense.' Is this not rather a case of covering up their own retreat by creating confusion about the issue?" (183). In Hayek's mind, he was not striking 
out on a new course, sharply distinct from Mises; rather, he was following up the implications of Mises's calculation arguments, which, as far back as 1912, themselves suggested the importance of prices as proxies for subjectively held knowledge.

\section{Some Implications for Money's Role in the Project of Economics}

There are two general reasons why it is important to stress that Mises's calculation argument was rooted in his understanding of the roles of money and monetary exchange. The first concerns the relationship between economic theory and economic systems, while the second relates to economic policy and the efficiency of market economies.

Mises's argument boils down to the claim that what enables actors in market economies to calculate rationally is the existence of money prices, which requires that there be private property in the means of production. Recalling the Hayekian insight that money prices are reflections of subjective knowledge, the Mises-Hayek critique of planning implies a broad welfare standard for assessing either theoretical or historical economic systems. Namely, to what extent do such economies enable individual producers and consumers to reckon, or in Salerno's (1994, 112) words, "socially appraise," in terms of reliable money prices? Economic systems that facilitate economic calculation using money prices should outperform those that make such calculations more difficult or try to eliminate them completely. The reliability of monetary calculation becomes a benchmark for assessing alternative economic systems.

This has two implications. At the level of theory, it casts some skepticism on other welfare standards, particularly those derived from general equilibrium models. Such models lack money in any meaningful sense of the term, as the theory's foremost practitioners recognize. 18 The strong knowledge assumptions, the neglect of real historical time, and the given nature of tastes, technology, and resources imply that general equilibrium models are largely irrelevant to assessing the disequilibrium phenomena that pervade real-world economies. Mises saw this in 1922: "It is clear that under stationary conditions the problem of

18. See Horwitz 1992 a, chap. 1, for more on this claim and textual evidence on the problems of fitting money into general equilibrium models. 
economic calculation does not really arise. When we think of the stationary society, we think of an economy in which all the factors of production are already used in such a way as, under the given conditions, to provide the maximum of the things which are demanded by consumers. That is to say, under stationary conditions there no longer exists a problem for economic calculation to solve. The essential function of economic calculation has by hypothesis been performed" ([1922] 1981, 120). In line with later Austrian emphases on competition as a discovery process, Mises is suggesting that the role of monetary calculation is to attempt to find out what is demanded by consumers and the most efficient ways of producing those products. Where general equilibrium approaches see equilibrium prices as "sufficient statistics" to provide the information necessary to reach equilibrium (and assess alternative economic systems by how closely they approach that equilibrium), a more Austrian approach would ask how well disequilibrium prices serve as calculation aids that encourage producers to detect existing discoordination and create incentives to further coordinate economic activity. 19

In addition, general equilibrium models with full-information prices normally ignore questions of capital's heterogeneity, preferring to treat capital as an uncomplicated aggregate. By doing so, they remove what Mises saw as the condition that renders monetary calculation via money prices necessary. Moreover, when heterogeneity is understood as not merely heterogeneity in use, but heterogeneity as subjectively appraised by individuals, the incompatibility of general equilibrium theory and Mises's discussion of monetary calculation becomes even more clear. Fully understanding money's role in the Mises-Hayek critique of planning would reorient welfare economics away from moneyless general equilibrium models toward assessing how well actors in disequilibrium can calculate and coordinate.

In a Lange-type model, where the relevant economic data are known to planners and where prices are treated parametrically, Misesian arguments about the indispensibility of monetary calculation will indeed seem strange. Monetary calculation and the social process of competitive appraisement that it involves are necessary precisely because the future is uncertain. As a result, it makes no sense to see prices as parametric. To the contrary, when heading into a sea of uncertainty, the 
whole point of entrepreneurial appraisement and monetary calculation is to act in such a way as to change prices so that the entrepreneur might profit. Again, on this line of reasoning, the Lange models fail because the prices they involve derive only from the appraisement of the planning board and not from the entire money-using market, as would be the case with private ownership of the means of production. Langean accounting prices cannot be distillations of the dispersed and subjective knowledge of market actors because there are no acts of monetary exchange and calculation that would draw out that knowledge. Such accounting prices are literally meaningless, precisely because they inappropriately transfer the assumptions needed to find an equilibrium price vector in a world of certainty to a world where uncertainty and imperfect knowledge are pervasive, necessitating monetary exchange and calculation. This is the source of the misunderstanding of the Mises-Hayek argument identified by Lavoie: Austrians were always talking about a world very different from the one assumed in static general equilibrium models, and much of the confusion derived from those differences.

The second implication of a fuller recognition of money's role in economic calculation is the assessment of alternative monetary regimes. One of the animating concerns of TMC is inflation and its consequences for market economies. Mises spends a great deal of time in the chapter on the objective exchange value of money explaining the effects of inflation, particularly the way in which an excess supply of money causes relative price effects. The problem with such effects is that they disrupt the process of economic calculation based on money prices. By adding an influence on money prices other than the decisions made by sellers and buyers (who have earned buying power from previous sales), inflation distorts the "chain" that runs from "deep in the human mind" to money prices in the market. To the extent it disrupts these calculations, we expect economic efficiency to be hampered. ${ }^{20}$

Mises also hinted at this argument in the 1920 calculation article: "For the practical purposes of life monetary calculation as it exists under a sound monetary system always suffices" ([1920] 1935, 109; emphasis added). Although Mises never returns to the point in that essay, reading that passage in light of TMC leads one to believe that Mises was concerned with the effects of inflation (and deflation, pre- 
sumably) on economic calculation. The implication of the emphasized phrase is that under an unsound monetary system, economic calculation would break down and no longer "suffice." If so, this provides a microeconomic assessment process for monetary policy. We can evaluate alternative monetary regimes by examining their effects on the process of economic calculation and the resulting (lack of) coordination. Regimes that avoid inflation and deflation are to be desired not just because they stabilize the aggregate price level and ease the expectational burden on actors, but because they prevent socially unnecessary disturbances to individual money prices that undermine their ability to serve as knowledge providers in disequilibrium. Monetary disequilibria thus undermine the process of monetary calculation, hampering entrepreneurship and therefore making it harder for the microeconomic market process to produce orderly outcomes. One task of monetary theory then becomes assessing, both theoretically and historically, how well various monetary regimes could or did prevent such monetary disequilibria and the microeconomic discoordination that follow them..$^{21}$ In terms of one of the explicit tasks of TMC, one can also see this argument as a way of linking microeconomics with monetary theory.

\section{Conclusion}

When Mises's 1920 critique of economic planning is read as part of a continuing line of argument begun with The Theory of Money and Credit in 1912 and extending to Human Action in 1966, it adds some new wrinkles to both the Austrian critique and the way in which that critique was misunderstood by the market socialists. Mises was always concerned with prices as they emerged in a money-using economy. He was not confused about, nor did he forget, what Lange ([1936] 1964, 59-60) refers to as the "broader" notion of prices as "terms on which alternatives are offered." He rejected such notions (and the other trappings of equilibrium theory) as being irrelevant to the real economic problem, which was how producers and consumers assessed the value

21. This can explain why Austrian monetary theorists have taken such an interest in a completely deregulated "free banking" system. Not only do its proponents claim it would avoid the disruptive problems of inflation and deflation, but also it takes advantage of the epistemic role of the price system by completely turning over the production of moncy to the competitive discovery process of the market. See Selgin 1988 and Horwizz 1992a for Austrian treatments of free banking. 
of goods of various orders of production in a dynamic monetary economy complete with heterogeneous capital goods. Mises could be read as arguing that capitalism is desirable because it brings the market closer to a Walrasian general equilibrium that is Pareto-optimal; but that completely misses his central argument and the argument's roots in Austrian thinking about the role of money in the market process. The references to economic calculation in TMC clarify this issue. As scholarship in both the history of economic thought and comparative economic systems continues to explore these issues, Mises's argument needs to be understood as rooted in both his monetary economics and, more broadly, his Austrian approach.

\section{References}

Boettke, Peter J. 1990. The Political Economy of Soviet Socialism: The Formative Years, 1918-1928. Boston: Kluwer Academic Press.

- 1993. Why Perestroika Failed. New York: Routledge.

1996. Review of Joseph Stiglitz's "Whither Socialism?" Journal of Economic Literature 34. 1: 189-91.

Cottrell, Allin, and W. Paul Cockshott. 1993. Calculation, Complexity, and Planning: The Socialist Calculation Debate Once Again. Review of Political Economy $5.1: 73-112$

Hayek, F. A. [1937] 1948. Economics and Knowledge. In Individualism and Economic Order. Chicago: University of Chicago Press.

- [1940] 1948. The Competitive Solution. In Individualism and Economic Order. Chicago: University of Chicago Press.

- [1945] 1948. The Use of Knowledge in Society. In Individualism and Economic Order. Chicago: University of Chicago Press.

. 1967. The Results of Human Action but Not of Human Design. In Studies in Philosophy, Politics, and Economics. Chicago: University of Chicago Press.

1973. Law, Legislation, and Liberty, vol. 1. Chicago: University of Chicago Press.

. 1977. Law, Legistation, and Liberty, vol. 2. Chicago: University of Chicago Press.

1978. Competition as a Discovery Procedure. In New Studies in Politics, Philosophy, Economics and the History of Ideas. Chicago: University of Chicago Press.

1989. The Fatal Conceit: The Errors of Socialism. Edited by W. W. Bartley III. Chicago: University of Chicago Press.

Hilferding, Rudolf. 1910 [1981]. Finance Capital. London: Routledge and Kegan Paul.

Horwitz, Steven. 1992a. Monetary Evolution, Free Banking. and Economic Order. Boulder: Westview Press. 
1992b. Monetary Exchange as an Extra-Linguistic Social Communication Process. Review of Social Economy 50.2:193-214.

. 1994. Inflation. In The Elgar Companion to Austrian Economics, edited by Peter J. Boettke. Aldershot: Edward Elgar.

. 1996. Money, Money Prices, and the Socialist Calculation Debate. Advances in Austrian Economics 3:59-77.

Kirzner, Israel. 1973. Competition and Entrepreneurship. Chicago: University of Chicago Press.

- 1992. Prices, the Communication of Knowledge and the Discovery Process. In The Meaning of Market Process. New York: Routledge.

1996. Reflections on the Misesian Legacy in Economics. The Review of Austrian Economics 9.2:143-54.

Lange, Oscar. [1936] 1964. On the Economic Theory of Socialism. In On the Economic Theory of Socialism, edited by Benjamin Lippincott. New York: McGrawHill.

Lavoie, Donald C. 1985. Rivalry and Central Planning. Cambridge: Cambridge University Press.

1986. The Market as a Procedure for the Discovery and Conveyance of Inarticulate Knowledge. Comparative Economic Studies 28.1:1-19.

Mises, Ludwig von. 1912. Theorie des Geldes und der Umlaufsmittel. Munich: Duncker and Humbolt.

[1912] 1980. The Theory of Money and Credit. Indianapolis: Liberty Press.

. [1920] 1935. Economic Calculation in the Socialist Commonwealth. In Collectivist Economic Planning, edited by F. A. Hayek. Clifton, N.J.: Augustus M. Kelley.

[1922] 1981. Socialism: An Economic and Sociological Analysis. Indianapolis: Liberty Press.

. [1949] 1966. Human Action: A Treatise on Economics. 3d ed. Chicago: Henry Regnery.

. [1957] 1985. Theory and History. Auburn, Ala.: Ludwig von Mises Institute.

Polanyi, Michael. 1957. The Foolishness of History. Encounter 9.5:33-37.

Rothbard, Murray N. 1995. The Present State of Austrian Economics. Journal des Economistes et des Etudes Humaines 6.1:43-89.

Salerno, Joseph T. 1990. Ludwig von Mises as Social Rationalist. The Review of Austrian Economics 4.1:26-54.

. 1993. Mises and Hayek Dehomogenized. The Review of Austrian Economics 6.2:113-46.

1994. Reply to Leland Yeager on "Mises and Hayek on Calculation and Knowledge." The Review of Austrian Economics 7.2:111-25.

Selgin, George A. 1988. The Theory of Free Banking: Money Supply under Competitive Note Issue. Totowa, N.J.: Rowman and Littlefield.

Simmel, Georg. [1907] 1978. The Philosophy of Money. Boston: Routledge and Kegan Paul. 
Steele, David Ramsay. 1992. From Marx to Mises. LaSalle, Ill.: Open Court.

Stiglitz, Joseph. 1994. Whither Socialism? Cambridge: MIT Press.

Thomsen, Esteban. 1992. Prices and Knowledge: A Market-Process Perspective. New York: Routledge.

Yeager, Leland B. 1994. Mises and Hayek on Calculation and Knowledge. The Review of Austrian Economics 7.2:93-109.

1996. Rejoinder: Salerno on Calculation, Knowledge, and Appraisement. The Review of Austrian Economics 9.1:137-39. 